\title{
Piebaldism: about an Observation and Review of the Literature
}

\author{
Iteke M, Tshilombo JM*, Kasongo F, Nkwembe R and Kakiesse V \\ Department of Dermatology, University Clinics of Kinshasa, Republic of the Congo
}

Submission: July 19, 2018; Published:September 24, 2018

*Corresponding author: Tshilombo JM, Department of Dermatology, University Clinics of Kinshasa, Republic of the Congo,

Email:drtshilombo@gmail.com

\begin{abstract}
The authors describe a case of piebaldism in a child of 1 year and a half and make a brief review of the literature. Piebaldism is a rare and benign condition. His diagnosis is clinical, after elimination of other differential diagnoses.
\end{abstract}

Keywords: Piebaldism; Depigmentation; Skin; Hair; Hypomelanosis

\section{Introduction}

The presence of localized hypomelanosis of the skin and hair in a newborn should lead the clinician to evoke a rare genetic disease such as piebaldism. We report here a case of piebaldism observed at the University Clinics of Kinshasa and address, through a review of the literature, its epidemiological, clinical and therapeutic aspects.

\section{Observation}

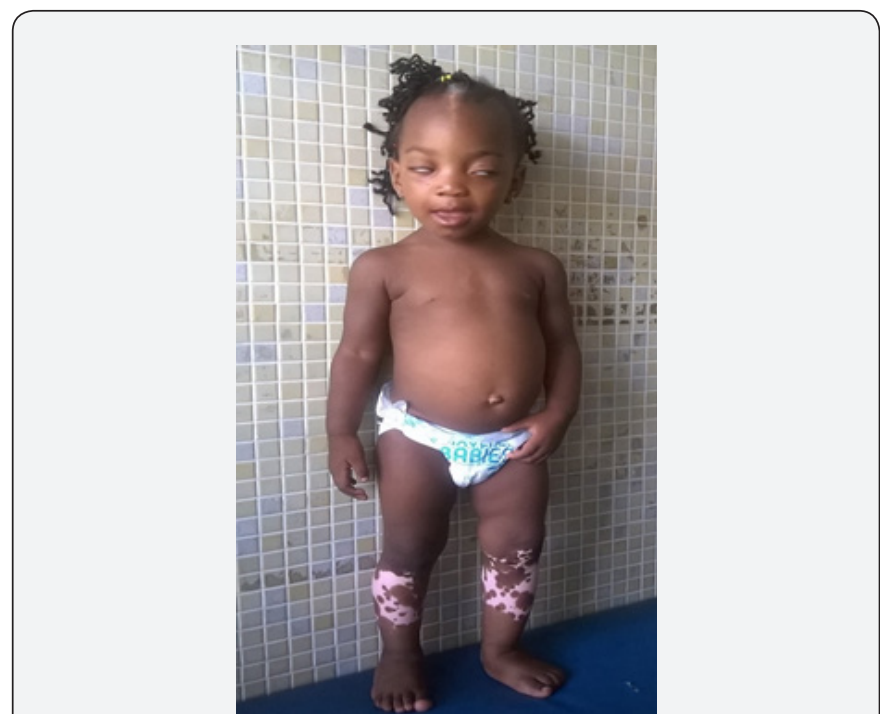

Figure 1: White wick on the front and hypochromic macules on the lower limbs in our patient.

IM, $1 \frac{1}{2}$ years old, is the result of a non-consanguineous marriage. She is born to term and has a psychomotor development normal for her age. This child was followed since birth for multiple hypopigmented lesions. The heteroanamnesis reveals the presence of the same abnormalities in his great-

grandmother, without association with other pathologies. At the clinical examination, it was a child in good condition with hypopigmented tablecloths of interest to the lower limbs dotted with normally pigmented skin. In addition, the child also had hypopigmented triangular hair involvement in the mid-front scalp. ENT, ophthalmic and cardiovascular examinations were normal. On all of these clinical data, the diagnosis of piebaldism was retained.

Protection advice for hypopigmented areas of the skin as well as the application of a cream with sunscreen have been prescribed to avoid complications (Figure 1).

\section{Discussion}

Piebaldism has been described for a long time throughout history with early writings by Egyptians, Greeks and Romans $[1,2]$. It is a pigmentation disorder of genetic origin with autosomal dominant inheritance [3]. It is a mild, rare disease whose incidence is estimated at less than $1 / 20000$ live births

$[4,5]$. This pigment anomaly results from a mutation in the proto-oncogene KIT at chromosome 4, or in the gene SLUG at chromosome 8; these mutations are responsible for a lack of migration and differentiation of melanoblasts during embryogenesis [6-8].

Clinically, this syndrome is manifested by the presence, at birth, depigmented spots that may interest the face, chest, abdomen, extremities. These spots are stable and persistent with distribution symmetry [9]. A lock of white hair, often triangular in shape, is present on the front of the scalp, sometimes with the underlying forehead [10]. In 80 to $90 \%$ of cases, this frontal white lock may be the only clinical manifestation $[2,11]$. Eyelashes 
and eyebrows can also be achieved. Typically, additional hyperpigmented macules can develop in the white plaques [9].

Diagnosis of piebaldism is clinical after elimination of other differential diagnoses. The main differential diagnoses are albinism, Waardenburg syndrome, tuberous sclerosis, vitiligo, Vogt-Koyanagi-Harada syndrome, Alezzandrini syndrome, alopecia areata and sarcoidosis [4]. Rare cases of association of piebaldism with other diseases, such as Hirschprung's disease, neurofibromatosis type 1, Blackfan-Diamond anemia glycogenosis type $1 \mathrm{a}$ have been described in the literature [4$5,12]$.

From a therapeutic point of view, areas of skin depigmented in piebaldism are generally insensitive to drug treatments and phototherapy [4], but it is important to protect them from sunstrokes by using protective creams to avoid a transformation. malignant [11]. Transplantation of the skin with the aid of the technique of mini-grafting, effective in $80 \%$ of cases, would currently be the best alternative [5].

\section{Conclusion}

Piebaldism is a mild illness but can have psycho-social repercussions. Therapeutic research is underway, including genetic therapy to improve the quality of life of patients.

\section{References}

1. Isabelle T, George GK, Michael DF, Camilia KJ, Robert AS (2004) Piebaldism: an update. International journal of dermatology 43(10): 716-719.
2. Kerkeni E, Boubaker S, Sfar S, Bizid M, Beebes H, et al. (2015) Molecular characterization of piebaldism in a Tunisian family. Pathologie Biologie 63(3): 113-116.

3. Bahadoran P, Lisker P (2009) Manuel du résident dermatologie. Edition Tsunami. exclusivité: PP. 98-585-A-10.

4. Grob A, Grekin S (2016) Piebaldism in children. Cutis 97(2): 90-92.

5. Agarwal S, Ojha A (2012) Piebaldism: a brief report and review of the literature. Indian Dermatology online Journal 3(2): 144-147.

6. Oiso N, Fukai K, Kawada A, Suzuki T (2013) Piebaldism. J Dermatol 40(5): 330-335.

7. Nagaputra JC, Koh MJA, Brett M, Lim ECP, Lim HW, et al. (2018) Piebaldisme with multiple café-au -lait-like hyperpigmented macules and inguinal freckling caused by a novel KIT mutation. JAAD Case Rep 4(4): 318-21.

8. Zheng Y, Liu F, Yang Y, Liang Y (2017) Novel KIT missense mutation P665S in a Chinese piebaldisme family. Ann Dermatol 29(6): 801-803.

9. El Kouarty H, Dakhama BS (2016) Piebaldism: a pigmentary anormaly to recognize: about a case and review of the literature. Pan Afr Med ] 25: 155.

10. Bassi A, Berti S, Galeone M (2015) Piebaldism clinical picture. QJM 108(11): 915-916.

11. Mallory Susan B, Alanna Bree, Peggy Chern (2007) Dermatologie pédiatrique. Issy-les-moulineaux: Elsevier Masson.

12. Ghoshal B, Sarkar N, Bhattacharjee M (2012) Glycogen storage disease 1a with piebaldisme. Indian Pediatr 49(3): 235-236.

\section{Your next submission with Juniper Publishers will reach you the below assets}

- Quality Editorial service

- Swift Peer Review

- Reprints availability

- E-prints Service

- Manuscript Podcast for convenient understanding

- Global attainment for your research

- Manuscript accessibility in different formats

( Pdf, E-pub, Full Text, Audio)

- Unceasing customer service

\section{Track the below URL for one-step submission}

https://juniperpublishers.com/online-submission.php 